\title{
Technology and Engineering
}

\section{Three-dimensional vs Standard Laparoscopy: Comparative Assessment Using a Validated Program for Laparoscopic Urologic Skills}

\author{
Antonio Cicione, Riccardo Autorino, Alberto Breda, Marco De Sio, Rocco Damiano, \\ Ferdinando Fusco, Francesco Greco, Emanuel Carvalho-Dias, Paulo Mota, \\ Cristina Nogueira, Pedro Pinho, Vincenzo Mirone, Jeorge Correia-Pinto, Jens Rassweiler, \\ and Estevao Lima
}

\begin{tabular}{|c|c|}
\hline OBJECTIVE & $\begin{array}{l}\text { To compare the last generation of 3-dimensional imaging (3D) vs standard 2-dimensional } \\
\text { imaging (2D) laparoscopy. }\end{array}$ \\
\hline MATERIALS AND & A prospective observational study was conducted during the 4th Minimally Invasive Urological \\
\hline METHODS & $\begin{array}{l}\text { Surgical Week Course held in Braga (Portugal) in April 2013. The course participants and faculty } \\
\text { were asked to perform standardized tasks in the dry laboratory setting and randomly assigned into } \\
2 \text { study groups; one starting with 3D, the other with 2D laparoscopy. The } 5 \text { tasks of the European } \\
\text { Training in Basic Laparoscopic Urological Skills were performed. Time to complete each task and } \\
\text { errors made were recorded and analyzed. An end-of-study questionnaire was filled by the } \\
\text { participants. }\end{array}$ \\
\hline RESULTS & $\begin{array}{l}\text { Ten laparoscopic experts and } 23 \text { laparoscopy-naïve residents were included. Overall, a signifi- } \\
\text { cantly better performance was obtained using } 3 \mathrm{D} \text { in terms of time }(1115 \text { seconds, interquartile } \\
\text { range }[\mathrm{IQR}] 596-1469 \text { vs } 1299 \text { seconds, IQR } 620-1723 ; P=.027) \text { and number of errors }(2 \text {, } \\
\mathrm{IQR} 1-3 \text { vs } 3 \text {, IQR } 2-5.5 ; P=.001) \text {. However, the experts were faster only in the "peg } \\
\text { transfer" task when using the 3D, whereas naïves improved their performance in } 3 \text { of the } 5 \\
\text { tasks. A linear correlation between level of experience and performance was found. Three- } \\
\text { dimensional imaging was perceived as "easier" by a third of the laparoscopy-naïve partici- } \\
\text { pants }(P=.027) \text {. }\end{array}$ \\
\hline CONCLUSION & $\begin{array}{l}\text { Three-dimensional imaging seems to facilitate surgical performance of urologic surgeons without } \\
\text { laparoscopic background in the dry laboratory setting. The advantage provided by 3D for those } \\
\text { with previous laparoscopic experience remains to be demonstrated. Further studies are needed to } \\
\text { determine the actual advantage of 3D over standard 2D laparoscopy in the clinical } \\
\text { setting. UROLOGY } 82 \text { : 1444-1450, 2013. C } 2013 \text { Elsevier Inc. }\end{array}$ \\
\hline
\end{tabular}

$\mathrm{L}$ aparoscopy has been increasingly adopted in urology over the last 2 decades, and it is nowadays commonly used in the management of several urologic diseases. Traditionally, laparoscopy has been based on 2-dimensional (2D) imaging, which has represented a considerable challenge for those approaching

\footnotetext{
Financial Disclosure: The authors declare that they have no relevant financial interests. From the Life and Health Sciences Research Institute, Universidade do Minho, Braga, Portugal; the Urology Unit, Second University, Naples, Italy; Glickman Urological and Kidney Institute, Cleveland Clinic, Cleveland, OH; the Department of Urology, Universidad Autonoma de Barcelona, Fundaciò Puigvert, Barcelona, Spain; the Urology Unit, Magna Graecia University, Catanzaro, Italy; the Department of Urology, Federico II University, Napoli, Italy; the Department of Urology and Renal Transplantation, Martin-Luther-University, Halle/Saale, Germany; and the Department of Urology, SLK Kliniken Heilbronn, Heilbronn, Germany

Reprint requests: Riccardo Autorino, M.D., Ph.D., F.E.B.U., Center for Laparoscopic and Robotic Surgery, Glickman Urological and Kidney Institute, Cleveland Clinic, 9500 Euclid Avenue Q10, Cleveland, OH 44195. E-mail: autorir@ccf.org

Submitted: June 13, 2013, accepted (with revisions): July 18, 2013
}

this technique. ${ }^{1}$ Thus, 3 -dimensional (3D) visualization technology for laparoscopy has been proposed, since the early 1990s, as a way to facilitate laparoscopic performance. However, early 3D laparoscopic technology was limited in terms of image quality, so that its use had not been implemented.

More recently, industry has developed novel 3D systems where the imaging is similar to stereoscopic vision, in which the depth perception is achieved by different unique images received by each eye. Thus, more recent studies have suggested a possible advantage provided by these new 3D systems during laparoscopic performance. ${ }^{3-5}$ However, comparative assessments of new generation 3D vs 2D laparoscopy remain limited, especially in the urology field.

The aim of this study was to compare the effect of 3D imaging on laparoscopic performance in the laboratory 
setting using a recently developed validated assessment tool.

\section{MATERIALS AND METHODS}

\section{Participants and Setting}

The present study was carried out at the Life and Health Sciences Research Institute, School of Health Sciences, University of Minho, during the 4th Minimally Invasive Urological Surgical Week annual course in Braga, Portugal in April 2013. Faculty members and course participants agreed to participate and were included in the study. Each participant was asked to complete standardized tasks in the dry laboratory, using both 2D and 3D systems. A computer-generated randomization sequence was used to allocate the participants in 2 study groups; the first starting with 3D laparoscopy, the second with 2D laparoscopy.

\section{Task Description}

The 5 exercises of the European Training in Basic Laparoscopic Urological Skills (E-BLUS) were performed by each participant. ${ }^{6}$ The E-BLUS was designed on the basis of the widely used Fundamentals of Laparoscopic Surgery program, with the addition of 2 tasks specifically conceived for urology training purposes. The face, content, and construct validity of E-BLUS were previously demonstrated. Briefly, the E-BLUS exercises consist of the following exercises: exercise 1 - to transfer objects one by one from one side of the board to the other and back avoiding to drop objects; exercise 2 - to cut a circle keeping within 2 black lines avoiding to cut in or beyond the 2 black lines; exercise 3 - to tie a single knot with 1 double-throw and 2 single-throws ensuring close margins juxtaposition; exercise 4 - to clip and cut a red tube (artery), followed by a blue tube (vein) avoiding to place clips or cut outside line limits; exercise 5 - to guide a needle through then rings, following a indicated route in which entering a ring from the wrong side was considered error. Each exercise was explained to the participants with a video. Moreover, each participant was allowed 5 minutes to familiarize with the exercise. The tasks were performed using 2 boxes trainer equipped with E-BLUS exercises, standard laparoscopic instruments (Karl Storz, Germany), Hem-o-lok applier (Teleflex), Vycril 3-0 sutures (Ethicon), and fixedposition $2 \mathrm{D}$ or $3 \mathrm{D}$ video camera with dedicated glasses.

\section{Imaging System}

Two working stations were used. The first one was equipped with the new 3D Karl Storz camera system attached to a 32" monitor. The other one was equipped with the latest generation of Karl Storz 2D high definition (HD) laparoscopic system, connected to a laparoscopic video tower with an HD flat screen video monitor. A fixed $10-\mathrm{mm}$ telescope $0^{\circ}$ was used as optic for both stations.

\section{Outcomes Measures}

Before performing laparoscopic tasks, each participant completed a baseline demographic questionnaire about age, practice setting (private, community, or teaching hospital), position (resident or postgraduated), and previous laparoscopic experience (expert: $>50$ procedures/year; naïve: none previous experience). Time to perform the task and number of errors were recorded for each task and considered as performance score. Then, an end-of-study questionnaire was administered regarding subjective perception of $3 \mathrm{D}$ vision vs $2 \mathrm{D}$.
Table 1. Overall performance in completing the European Training in Basic Laparoscopic Urological Skills curriculum: comparison of the 2D vs 3D systems. Spearman coefficient $\left(r_{s}\right)$ for correlation between performance and laparoscopic experience

\begin{tabular}{|c|c|c|c|}
\hline Parameter & 2D & 3D & $P^{\dagger}$ \\
\hline $\begin{array}{l}\text { Time } \\
\text { used, s }\end{array}$ & $1299(620-1723) *$ & 1115 (596-1469)* & .027 \\
\hline $\begin{array}{l}\text { Error } \\
\quad \text { number } \\
\text { made, } \mathrm{n}\end{array}$ & $3(2-5.5)^{*}$ & $2(1-3) *$ & .001 \\
\hline $\begin{array}{l}r_{\mathrm{s}} \text { Time }^{\ddagger} \\
r_{\mathrm{s}} \text { Error } \\
\text { number }\end{array}$ & $\begin{array}{l}-699 \\
-446\end{array}$ & $\begin{array}{l}-755 \\
-461\end{array}$ & \\
\hline
\end{tabular}

* Values expressed as median interquartile range.

$\dagger$ Wilcoxon test.

${ }^{\ddagger}$ For each $r_{\mathrm{s}}$ a $P<.05$ was obtained.

\section{Statistical Analysis}

Statistical analysis was performed using the Statistical Package for Social Science 18.0 for Windows. Evaluation of data distribution showed a non-normal distribution of the study dataset. Wilcoxon test and Mann-Whitney test were used to analyze ordinal variables and Chi square test for categorical variables. Furthermore, Spearman correlation coefficient was rated to assess the correlation between the $2 \mathrm{D}$ or $3 \mathrm{D}$ performance and laparoscopic experience. A $P$ value $<.05$ was considered as the threshold for statistical significance.

\section{RESULTS}

Overall, 33 urologic surgeons participated in the study, including 10 "experts" (median age 45 years; interquartile range [IQR] 38-54) and 23 "laparoscopy-naïve" residents (median age 27 years; IQR 25-28; $P=0.001$ ). Most of the participants worked in a teaching hospital (29 of 33; $87.8 \%$ ).

Table 1 summarizes the overall time used to complete the task and number of errors using 2D or 3D system. The use of 3D was associated with a faster (median 1115 [IQR: 596-1469] vs 1299 [IQR: 620-1723] seconds; $P=.027$ ) and more precise (median 2 [IQR: 1-3] vs 3 [IQR: 2-5.5] errors; $P=.001$ ) performance. Moreover, a significant inverse correlation was found between previous laparoscopic experience and performance, with both the 2D and the 3D systems (Fig. 1).

Stratifying participants according to their laparoscopic experience and E-BLUS exercises, few significant differences between 2D and 3D laparoscopy were detected (Table 2; Fig. 1). In detail, "experts" were faster using the 3D only when performing peg transfer (exercise $1 ; P=$ $.01)$, whereas the "laparoscopic-naïve" were faster when carrying the clip and cut (exercise $4 ; P=.03$ ). Moreover, the "laparoscopic-naïve" participants were more accurate with the $3 \mathrm{D}$ in 3 of 5 exercises (peg transfer, $P=.03$; cut a circle, $P=.04$; clip and cut, $P=.01$ ), whereas "experts" demonstrated the same level of accuracy regardless the system used, as demonstrated by the similar number of errors made for all the exercises. 
A

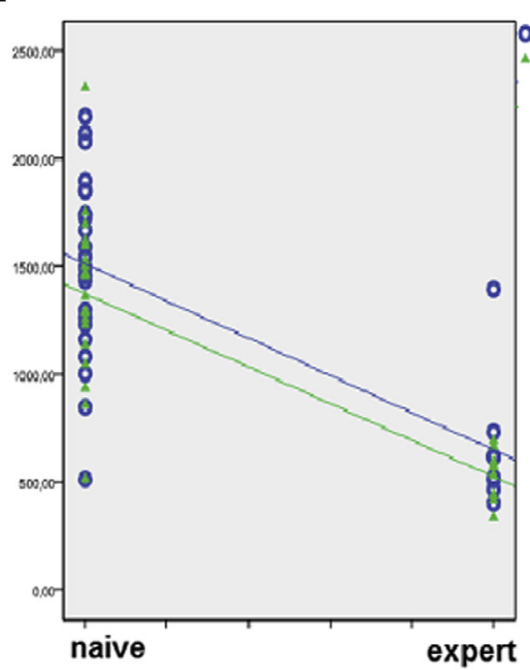

B

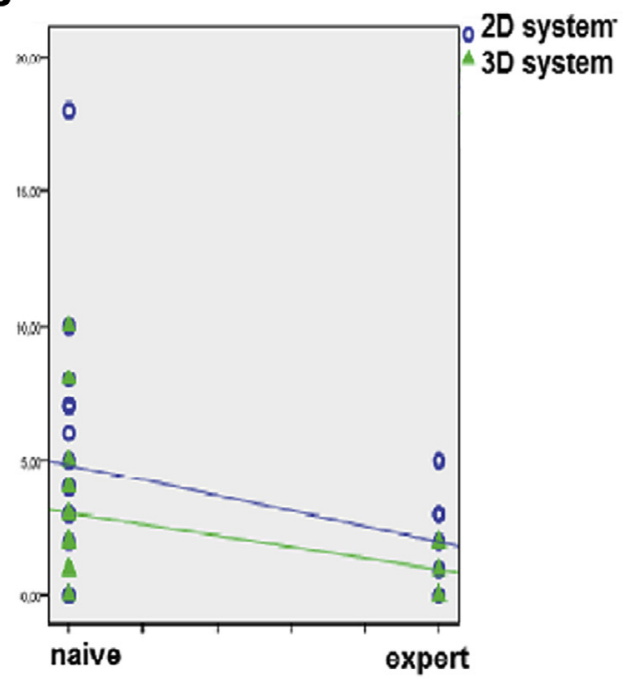

Figure 1. Execution time (A) and errors (B) made for the overall 5 European Training in Basic Laparoscopic Urological Skills task related to laparoscopic experience. (Color version available online.)

Overall, comparative assessment between experts and naïve suggested that previous experience with laparoscopy significantly improves task performance regardless of the system used.

In terms of subjective perception, participants indicated exercise number 5 (needle guidance) as the one with the highest benefit provided by the $3 \mathrm{D}$ vision ( $P$ not evaluable). Only $33 \%$ of the "laparoscopic-naïve" indicated the 3D laparoscopy to be easier than 2D laparoscopy, whereas for the other participants they were considered similar $(P=.027)$.

\section{COMMENT}

Despite its increasing adoption in urology over the last 2 decades, it is well established that laparoscopy carries intrinsic limitations, including reduced depth perception of the operative field caused by the use of 2D monitors, poor hand-eye coordination as a result of location of the monitor, variable amplification, and mirrored movement, and reduced haptic feedback from the use of long surgical instruments.

To partially overcome these challenges, recent technological advances allowed the development of 3D imaging with the rationale that an improved depth perception might translate into a better surgical performance. However, studies comparing 3D vs 2D systems have shown conflicting findings (Table 3 ). Moreover, available studies have been mostly done in the general surgery field, with only very limited evidence available for urology.

In the present study, we evaluated whether the use of a last generation $3 \mathrm{D}$ system provides an advantage in term of performance in a recently validated curriculum for urologic laparoscopy. ${ }^{6}$

Interestingly, although an overall significant advantage was found for the 3D in terms of time and precision during the assessed tasks, there was some degree of variability when stratifying participants according to their level of previous laparoscopic experience.

Those with previous laparoscopic background (defined as "experts") did not subjectively recognize an advantage with using 3D system, although they performed better with the peg transfer task, which was devised to assess the ambidexterity. Thus, it can be speculated that performing in 3D could facilitate hand versatility in surgeon with preexisting laparoscopic skills. The assumption is also supported by the finding that all the participants perceived "needle guidance" as the task where 3D system could translate in an actual benefit. Guiding a needle through sequential rings route was suggested as a method to train needle position, eye-hand coordination, and ambidexterity. ${ }^{6}$ This skill benefit could be translated in easier urologic surgical steps, such as performing urethral bladder neck anastomosis during radical laparoscopic prostatectomy or suturing during pyeloplasty.

Laparoscopic-naïve participants were more precise (ie, less number of errors) when using the 3D system in 3 over 5 tasks: "cutting a circle", "clipping and cutting", and "peg transfer". The "clipping and cutting" is a simplified representation of the clipping and cutting of the renal vessels that occurs during nephrectomy. As such, it can be regarded a specific urologic skill.

Another interesting finding was the overall correlation between "experience" and performance, which was found with both the 2D and the 3D. This finding supports the construct validity of the E-BLUS training program.

Our study findings are in line with recent studies, suggesting that a higher level of technology, from camera to image display, translates into a better performance in the laboratory setting. Honeck et $\mathrm{al}^{3}$ compared novices or experts laparoscopic surgeons using $2 \mathrm{D}$ vs $3 \mathrm{D}$ imaging and reported a slightly better performance with the 3D system. 


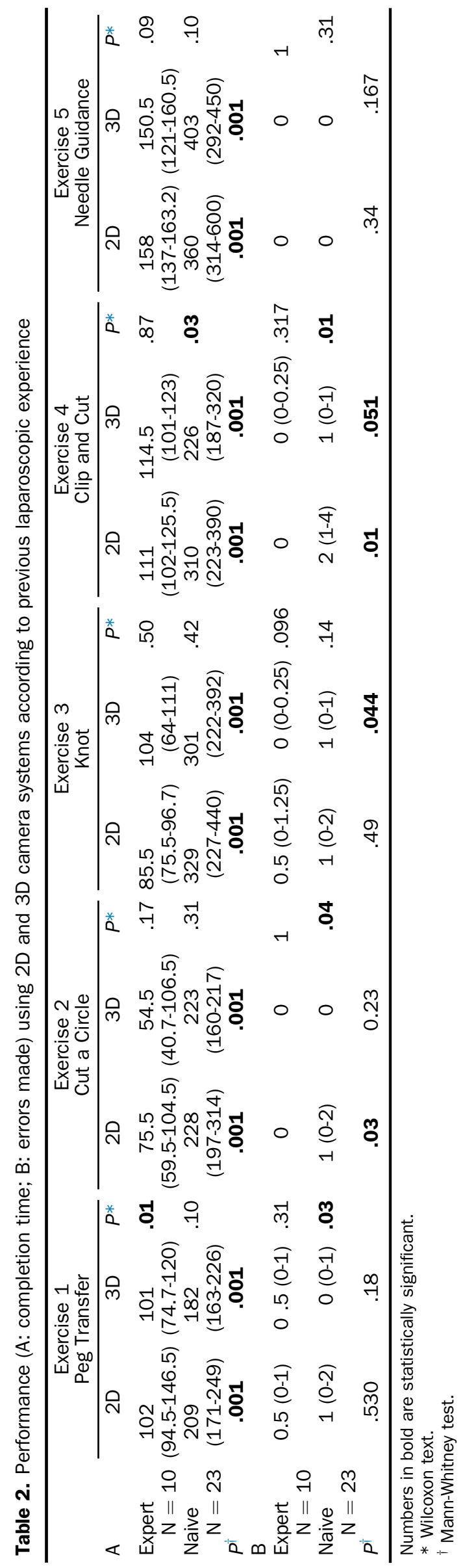

Moreover, they reported a better perception and spatial resolution among the experts with the use of the $3 \mathrm{D}$. In another recent study, enrolling 20 medical students and 10 laparoscopic experts, Storz et $\mathrm{al}^{7}$ showed that the use of 3D imaging allowed the surgeons to be faster and more accurate. In 4 of the 5 tasks, the study participants made fewer mistakes in 3D than in 2D vision. In 4 of the tasks, they needed significantly more time in the $2 \mathrm{D}$ mode. The student group and the expert group showed similarly improved performance, whereas the surgeon group additionally saved more time on difficult tasks. The authors concluded that 3D HD using a state-of-the-art 3D monitor permits superior task efficiency, even as compared with the latest 2D HD video systems. In our study, the benefit of the 3D was more significant for laparoscopic-naïve urologists than experts in carrying standardized tasks.

Notably, the present study represents the first to use an assessment tool specifically designed for urology, which was also recently adopted by the European Association of Urology Section of Uro-Technology for the development of the E-BLUS program. This tool was already validated in terms of face, content, and construct validity. ${ }^{6}$ In general, the fact of using a standardized and validated tool enabled us to perform a reliable and objective analysis.

However, limitations of the study itself are to be recognized. Despite our study sample comparing favorably with those in other similar studies, we did not formally power the study so that differences between the study groups might have been left undetected. Moreover, in clinical practice, the scope can be moved to have more depth spatial information, ${ }^{8}$ whereas in our study, the camera was maintained in a predetermined fixed position. Ultimately, our experience was carried out in a laboratory setting, so that it remains to be determined the translation of these findings in the clinical setting, in which other factors, besides the technology itself, play a major role in determining surgical performance. In other words, actual laparoscopic procedures represent a more challenging task; thus, the predictive validity of the E-BLUS remains to be further studied. In this respect, clinical studies comparing 3D vs 2D are still limited; Gurusamy et $\mathrm{al}^{9}$ found no evidence that $3 \mathrm{D}$ is superior to $2 \mathrm{D}$ in laparoscopic cholecystectomy in the clinical setting in terms of postoperative complications, conversion to open surgery, and operating time.

\section{CONCLUSION}

The latest generation of 3D imaging for laparoscopy seems to facilitate surgical performance of urologic surgeons without laparoscopic background. For those with established laparoscopic background, the advantage provided by the use of $3 \mathrm{D}$ remains to be determined. Further studies with larger sample size are needed to determine the actual effect of using 3D laparoscopy in the clinical setting. 
Table 3. Overview on main comparative studies about 3D vs $2 \mathrm{D}$ laparoscopic systems

\begin{tabular}{|c|c|c|c|c|c|}
\hline Ref. & Participants & 3D System & 2D System & Task Performed & Authors Conclusions \\
\hline $\begin{array}{l}\text { Hanna GB } \\
\text { et }^{10}{ }^{10}\end{array}$ & $\begin{array}{c}\text { Four specialist } \\
\text { registrars }\end{array}$ & $\begin{array}{l}\text { 3D-video and camera } \\
\text { system (Carl Zeiss) }\end{array}$ & $\begin{array}{c}\text { Three chip camera } \\
\text { (Karl Storz) }\end{array}$ & $\begin{array}{l}\text { RCT on } 60 \text { VLP } \\
\text { cholecystecomies. } \\
\text { Four surgery steps } \\
\text { adopted as task: } \\
\text { 1. Dissection of cystic } \\
\text { duct and artery in } \\
\text { Calot's triangle } \\
\text { 2. Insertion of catheter } \\
\text { for cholangiography } \\
\text { 3. Ligation of cystic } \\
\text { duct and external } \\
\text { knot } \\
\text { 4. Separation of gall- } \\
\text { bladder from the } \\
\text { liver bed }\end{array}$ & $\begin{array}{l}\text { Better subjective } \\
\text { depth perception } \\
\text { using 3D but 2D } \\
\text { was judged better } \\
\text { in terms of } \\
\text { sharpness, } \\
\text { contrast, and } \\
\text { ghosting. }\end{array}$ \\
\hline $\begin{array}{l}\text { McDougall } \\
\text { ME } \\
\text { et } a l^{11}\end{array}$ & $\begin{array}{c}\text { Twenty-two between } \\
\text { urology or } \\
\text { gynecology VLP } \\
\text { experts }\end{array}$ & $\begin{array}{l}\text { Endolive Stereo } \\
\text { Endoscope system } \\
\text { (Carl Zeiss) and } \\
\text { StereoVu Video } \\
\text { Laparoscope } \\
\text { system (Welch } \\
\text { Allyn Surgical } \\
\text { Imaging System) }\end{array}$ & $\begin{array}{c}\text { Conventional } \\
\text { systems of } \\
\text { Circom/ACMI, } \\
\text { Olympus, Karl } \\
\text { Storz, Richard Wolf } \\
\text { Medical } \\
\text { Instruments }\end{array}$ & $\begin{array}{c}\text { Eleven } 2 \mathrm{D} \text { and nine } 3 \mathrm{D} \\
\text { retroperitoneal } \\
\text { nephrectomies in } \\
\text { pigs } \\
\text { Sixteen } 2 \mathrm{D} \text { and } 11 \\
\text { Burch bladder neck } \\
\text { suspensions in } \\
\text { pigs. }\end{array}$ & $\begin{array}{c}\text { For all the surgeons, } \\
\text { the 3D system did } \\
\text { not improve image } \\
\text { quality and } \\
\text { procedure } \\
\text { performance. }\end{array}$ \\
\hline $\begin{array}{l}\text { Kum CK } \\
\text { et }^{1}{ }^{12}\end{array}$ & $\begin{array}{l}\text { Thirteen medical } \\
\text { students and } 5 \\
\text { general surgeons }\end{array}$ & Baxter Healthcare & $\begin{array}{c}\text { Three-chip cameras } \\
\text { (Olympus) }\end{array}$ & $\begin{array}{c}\text { Performing a knot in } \\
\text { a training box }\end{array}$ & $\begin{array}{c}\text { 3D use significantly } \\
\text { faster both for } \\
\text { students and } \\
\text { surgeons. }\end{array}$ \\
\hline $\begin{array}{l}\text { Lagrange A } \\
\text { et al }\end{array}$ & $\begin{array}{c}\text { Seventeen medical } \\
\text { students, } 5 \\
\text { surgeons and } 5 \\
\text { residents ( } 2 \\
\text { urology }-1 \\
\text { gynecology }-2 \\
\text { surgeons); } \\
\text { randomized } \\
\text { starting }\end{array}$ & $\begin{array}{c}\text { Endosite 3Di visual } \\
\text { system (Viking } \\
\text { Systems) and } \\
\text { daVinci Robotic } \\
\text { Surgical System } \\
\text { (Intuitive Surgical) }\end{array}$ & $\begin{array}{l}\text { High-definition } \\
\text { cameras (Stryker) }\end{array}$ & $\begin{array}{l}\text { Three tasks from LTS- } \\
2000 \text { Simulator } \\
\text { (RealSim Systems): } \\
\text { peg transfer, ring } \\
\text { manipulation and } \\
\text { Cannulation }\end{array}$ & $\begin{array}{c}\text { Overall, 3D does not } \\
\text { confer an } \\
\text { advantage over } \\
\text { 2D. The 3D robot } \\
\text { offers advantage } \\
\text { in more } \\
\text { complicated tasks }\end{array}$ \\
\hline $\begin{array}{l}\text { Storz et al. } \\
\qquad(2012)^{7}\end{array}$ & $\begin{array}{l}\text { Twenty medical } \\
\text { students and } 10 \\
\text { VLP experts; } \\
\text { randomized } \\
\text { starting }\end{array}$ & $\begin{array}{c}\text { 6CCD stereo } \\
\text { endoscopic camera } \\
\text { head (Richard Wolf) }\end{array}$ & $\begin{array}{l}\text { 6CCD stereo } \\
\text { endoscopic } \\
\text { camera head } \\
\text { (Richard Wolf) }\end{array}$ & $\begin{array}{l}\text { Five tasks: } \\
\text { 1. Eight black circular } \\
\text { target spots had to } \\
\text { be touched }\end{array}$ & $\begin{array}{c}\text { Use of 3D improves } \\
\text { task efficiency } \\
\text { especially when } \\
\text { performing } \\
\text { difficult tasks }\end{array}$ \\
\hline & & & & $\begin{array}{l}\text { 2. Seven circular } \\
\text { target spots had } \\
\text { to be touched } 20 \\
\text { times in } \\
\text { a randomly } \\
\text { defined order }\end{array}$ & \\
\hline & & & & $\begin{array}{l}\text { 3. Move a metal loop } \\
\text { on a metal wire } \\
\text { without touch it }\end{array}$ & \\
\hline & & & & $\begin{array}{l}\text { 4. Move a straight } \\
\text { needle across } \\
\text { five holes }\end{array}$ & \\
\hline & & & & $\begin{array}{l}\text { 5. Continuous suturing } \\
\text { using a circular } \\
\text { needle }\end{array}$ & \\
\hline
\end{tabular}


Table 3. Continued

\begin{tabular}{|c|c|c|c|c|c|}
\hline Ref. & Participants & 3D System & 2D System & Task Performed & Authors Conclusions \\
\hline $\begin{array}{l}\text { Tanagho } \\
\text { Y.S. } \\
\text { et } \text { al }^{4}\end{array}$ & $\begin{array}{l}\text { Previous VLP skill } \\
\text { described as } 23 \\
\text { novices, } 5 \\
\text { intermediate, } 3 \\
\text { expert, } 2 \text { unsure; } \\
\text { randomized } \\
\text { starting. }\end{array}$ & $\begin{array}{l}\text { Viking 3DHD } \\
\text { Laparoscopic } \\
\text { Vision System } \\
\text { (Viking System) }\end{array}$ & $\begin{array}{l}\text { Viking 2DHD } \\
\text { Laparoscopic } \\
\text { Vision System } \\
\text { (Viking Systems) }\end{array}$ & $\begin{array}{l}\text { Three tasks of } \\
\text { Fundamentals of } \\
\text { Laparoscopic } \\
\text { Surgery program } \\
\text { (peg transfer, } \\
\text { pattern cutting, } \\
\text { suturing/knot tying) }\end{array}$ & $\begin{array}{l}\text { 3D use was shorter } \\
\text { in each task and } \\
\text { associated with } \\
\text { improved } \\
\text { precision. } \\
\text { Any potential side } \\
\text { effect from 3D use } \\
\text { occurred. }\end{array}$ \\
\hline $\begin{array}{r}\text { Kong SH } \\
\text { et } \mathrm{al}^{14}\end{array}$ & $\begin{array}{c}\text { Twenty-one medical } \\
\text { students and } 6 \\
\text { surgeons }\end{array}$ & $\begin{array}{c}\text { RAHPACAM 105i and } \\
\text { DV LENS (WDV- } \\
\text { 200H) (Wasol) }\end{array}$ & $\begin{array}{l}\text { OTV-S6, camera } \\
\text { head (Olympus) }\end{array}$ & $\begin{array}{c}\text { Task 1: put a thread in } \\
\text { six holes using two } \\
\text { mosquito } \\
\text { Task 2: using } \\
\text { a gastrectomy } \\
\text { training box vessel } \\
\text { dissection was } \\
\text { simulated }\end{array}$ & $\begin{array}{l}\text { Completion time } \\
\text { was not different. } \\
\text { Using 2D more } \\
\text { Errors were made. } \\
53.6 \% \text { of } \\
\text { participants } \\
\text { preferred 3D while } \\
\text { the } 16.7 \% \text { the 2D } \\
\text { and the } 29.8 \% \\
\text { tasted none } \\
\text { difference }\end{array}$ \\
\hline $\begin{array}{c}\text { Wagner OJ } \\
\text { et } \mathrm{al}^{5}\end{array}$ & $\begin{array}{l}\text { Thirty-four } \\
\text { participants with } \\
\text { mixed VLP } \\
\text { experience }\end{array}$ & $\begin{array}{l}\text { Binocular vision; } \\
\text { EndoSite 3Di } \\
\text { Digital Vision } \\
\text { System (Viking } \\
\text { Systems) and } \\
\text { DaVinci S Surgical } \\
\text { System (Intuitive } \\
\text { Surgical) in 3D } \\
\text { modality }\end{array}$ & $\begin{array}{l}\text { Monocular vision; } \\
\text { One 3CCD digital } \\
\text { Karl Storz system } \\
\text { and DaVinci S } \\
\text { Surgical System } \\
\text { (Intuitive Surgical) } \\
\text { in 2D modality }\end{array}$ & $\begin{array}{l}\text { Open vs 2D vs 3D } \\
\text { through the } \\
\text { performing of three } \\
\text { pods of The } \\
\text { Chamberlain Group: } \\
\text { Sea Spike Pod, } \\
\text { Suturing, S-Hook }\end{array}$ & $\begin{array}{c}\text { Task performance } \\
\text { with each } 3 \mathrm{D} \text { was } \\
\text { superior to that } \\
\text { with } 2 \mathrm{D}, \\
\text { independently of } \\
\text { surgeon } \\
\text { experience. } \\
\text { 3D robotic } \\
\text { performance was } \\
\text { superior to that } \\
\text { VLP in more } \\
\text { difficult task }\end{array}$ \\
\hline $\begin{array}{r}\text { Honeck } \\
\text { et al }\end{array}$ & $\begin{array}{c}\text { Ten experts and } 10 \\
\text { novices divided in } \\
2 \text { study group (2D } \\
\text { vs 3D) }\end{array}$ & $\begin{array}{c}\text { Einstein system, } \\
\text { Scholly Fiber- } \\
\text { optics, Germany }\end{array}$ & Karl Storz 2D system & $\begin{array}{l}\text { Five task: placing } \\
\text { three rings in } \\
\text { a three cones; } \\
\text { displacing the } \\
\text { previous rings; } \\
\text { needle passage } \\
\text { through a ring, } \\
\text { cutting a suture; } \\
\text { tying one knot. }\end{array}$ & $\begin{array}{c}\text { 3D system improved } \\
\text { task performance } \\
\text { event for expert } \\
\text { surgeons }\end{array}$ \\
\hline
\end{tabular}

RCT, randomized control trial; VLP, videolaparoscopy.

Acknowledgments. The authors thank the 4th Minimally Invasive Urological Surgical Week course attendees who participated in this study. They also thank The Research Endoscopic Laboratory at the University of Minho and the support of Karl Storz, Germany for providing instrumentation used in the study.

\section{References}

1. Janetschek G, Marberger M. Laparoscopic surgery in urology. Curr Opin Urol. 2000;10:351-357.

2. Kunert W, Storz P, Kirschniak A. For 3D laparoscopy: a step toward advanced surgical navigation: how to get maximum benefit from 3D vision. Surg Endosc. 2013 Feb;27:696-699.

3. Honeck P, Wendt-Nordahl G, Rassweiler J, Knoll T. Threedimensional laparoscopic imaging improves surgical performance on standardized ex-vivo laparoscopic tasks. J Endourol. 2012 Aug;26: 1085-1088.

4. Tanagho YS, Andriole GL, Paradis AG, et al. 2D versus 3D visualization: impact on laparoscopic proficiency using the fundamentals of laparoscopic surgery skill set. J Laparoendosc Adv Surg Tech A. 2012 Nov;22:865-870.
5. Wagner OJ, Hagen M, Kurmann A, et al. Three-dimensional vision enhances task performance independently of the surgical method. Surg Endosc. 2012 Oct;26:2961-2968.

6. Tjiam IM, Persoon MC, Hendrikx AJ, et al. Program for laparoscopic urologic skills: a newly developed and validated educational program. Urology. 2012 Apr;79:815-820.

7. Storz P, Buess GF, Kunert W, Kirschniak A. 3D HD versus 2D HD: surgical task efficiency in standardised phantom tasks. Surg Endosc. 2012 May;26:1454-1460.

8. Rogers B. Motion parallax as an independent cue for depth perception: a retrospective. Perception. 2009;38:907-911.

9. Gurusamy KS, Sahay S, Davidson BR. Three dimensional versus two dimensional imaging for laparoscopic cholecystectomy. Cochrane Database Syst Rev 2011 Jan 19:CD006882.

10. Hanna GB, Shimi SM, Cuschieri A. Randomised study of influence of two-dimensional versus three-dimensional imaging on performance of laparoscopic cholecystectomy. Lancet. 1998 Jan 24;351:248-251.

11. McDougall EM, Soble JJ, Wolf JS Jr, et al. Comparison of threedimensional and two-dimensional laparoscopic video systems. J Endourol. 1996 Aug;10:371-374.

12. Kum CK, Goh P, Alexander DJ, Moochala S. Three-dimensional versus two-dimensional imaging for laparoscopic suturing. Br J Surg. 1997 Jan;84:35. 
13. LaGrange CA, Clark CJ, Gerber EW, Strup SE. Evaluation of three laparoscopic modalities: robotics versus three-dimensional vision laparoscopy versus standard laparoscopy. J Endourol. 2008 Mar;22: 511-516.

14. Kong SH, Oh BM, Yoon H, et al. Comparison of two- and threedimensional camera systems in laparoscopic performance: a novel 3D system with one camera. Surg Endosc. 2010 May;24: $1132-1143$.

\section{EDITORIAL COMMENT}

I liked this simple study, although it was somewhat underpowered to underpin the proof of the concept; there were not enough participants, and the tasks perhaps were not as difficult to extrapolate the outcomes to those performed during complex laparoscopic surgery. The bottom line, however, was that comparative assessment suggested that previous experience with laparoscopy significantly improves task performance regardless of the system used; 3D might, however, flatten the learning curve for clinicians commencing their laparoscopic training. This is very important when we consider how we should go about setting up training for newcomers to the field of laparoscopic urologic surgery.

There remains a lot to be done to substantiate the concept proposed, especially its predictive validity, but this study certainly seems to be a step in the right direction.

Abhay Rane, M.S., F.R.C.S. (Urol), East Surrey Hospital, Canada Avenue, Redhill, United Kingdom

http://dx.doi.org/10.1016/j.urology.2013.07.052 UROLOGY 82: 1450, 2013. (c) 2013 Elsevier Inc. 